\title{
Determination of Some Heavy Metals in Roadside Soils from Some Major Roads in Maiduguri, Borno State, Nigeria
}

\author{
Mohammed Kyari Dikwa ${ }^{1}$, Joe Clement Akan², Aliyu Adamu ${ }^{3, *}$ \\ ${ }^{1}$ Department of Environmental Health Science, College of Health Technology Maiduguri, Borno, Nigeria \\ ${ }^{2}$ Department of Chemistry, University of Maiduguri, Borno, Nigeria \\ ${ }^{3}$ Department of Physics, University of Maiduguri, Borno, Nigeria
}

Email address:

mkyari@gmail.com (M. K. Dikwa), joechemakan@yahoo.com(J. C. Akan), aliyuadamu703@gmail.com (A. Adamu)

*Corresponding author

\section{To cite this article:}

Mohammed Kyari Dikwa, Joe Clement Akan, Aliyu Adamu. Determination of Some Heavy Metals in Roadside Soils from Some Major Roads in Maiduguri, Borno State, Nigeria. Nuclear Science. Vol. 4, No. 3, 2019, pp. 27-33. doi: 10.11648/j.ns.20190403.11

Received: March 2, 2019; Accepted: November 8, 2019; Published: November 17, 2019

\begin{abstract}
Heavy metal concentration in road side soils with its potential ecological effects draws much attention in the developing countries. This necessitates the study of their accumulation in the road side soils of Maiduguri (longitude $11^{\circ} 13^{\prime} \mathrm{N}$; latitude $13^{\circ} 05^{\prime} E$ ), to ensure effective protection of soil from the potential loss of its fertility. In this study, roadside soil samples from major roads (Baga road, Bama road, Ngala road and Kano/Jos road) of Maiduguri were collected and determined the levels of heavy metals $(A s, C r, M n, F e, N i, P b, Z n, C d$, and $\mathrm{Cu}$ ) in the roadside soil using the Perkin-Elmer analyst 300 Atomic Absorption Spectroscopy (AAS). The results showed that in all the sampling locations, $\mathrm{Mn}, \mathrm{Zn}, \mathrm{Fe}$ and $\mathrm{Pb}$ have higher concentration of $137.4 \pm 0.04 \mathrm{mg} / \mathrm{kg}, 392.11 \pm 0.07 \mathrm{mg} / \mathrm{kg}, 13491.70 \pm 0.07 \mathrm{mg} / \mathrm{kg}$ and $928.50 \pm 0.04 \mathrm{mg} / \mathrm{kg}$ respectively in roadside soil as compared with $C d$ of concentration ranges from 0 to maximum of $0.87 \pm 0.04 \mathrm{mg} / \mathrm{kg}$ in Ngala road. The concentrations of $\mathrm{Pb}$ and $\mathrm{Cd}$ in the soil samples were higher than the recommended value of $48 \mathrm{mg} / \mathrm{kg}$ and $5.0 \mathrm{mg} / \mathrm{kg}$ respectively. The higher concentration of these metals in the roadside soil samples may be attributed to human activities and traffic volume. Therefore, there is need to further study the concentrations of such heavy metals in agricultural soil, plants and vegetables grown in that area, animals that fed on the plants and any other source that directly or indirectly link to the source of food of the populace.
\end{abstract}

Keywords: Atomic Absorption Spectroscopy, Heavy Metals, Roadside Soil, Concentration, Traffic Volume Count

\section{Introduction}

Heavy metal are metallic elements that are having relatively higher density, they are poisonous or toxic to plants and animals at a certain concentration $[1,2]$. Road side soils are often contaminated with heavy metals due to different operations of the road transport such as combustion, oil spills, tire and break wear, corrosion of metals and batteries, erosion of road surfaces, metallic parts such as radiator, building materials, lead petrol product, construction work, iron bending and welding of metals. These activities contribute to $\mathrm{As}, \mathrm{Cr}, \mathrm{Mn}, \mathrm{Fe}, \mathrm{Ni}, \mathrm{Pb}, \mathrm{Zn}, \mathrm{Cd}$, and $\mathrm{Cu}$ contamination in road side soils. Theses heavy metals are released into the roadside environment as a result of mechanical abrasion and normal wear and tear. Soil tends to accumulate metals on a relatively long term basis since many metals in the soil are mobile [3-11].

The heavy metals present in soils can be transported to plant or animals by the action of water or wind. This may affect the quality of water and air. Inhalation, ingestion or dermal contact may post a severe risk to ecosystem and threaten human health. Heavy metal concentration in soil with its potential ecological effects has been a worldwide environmental concern for long time and attains much attention in the recent past. Therefore, it is necessary to have a continuous study on the accumulation of heavy metals in the soil to ensure effective protection of soil from the potential loss of its fertility. Although, there has been considerable number of studies on the concentrations of heavy metals in roadside soils, the vast majority has been carried out in developed countries with long histories of industrialization and extensive use of leaded gasoline since 
$1935[13,14]$. Very few studies have been carried out in developing countries such as Nigeria and data on heavy metal concentrations and distribution in such countries are extremely scarce.

Maiduguri is the capital of Borno State and, Borno State is the only state in Nigeria that is bordering three (3) countries (Chad, Niger and Cameroun) therefore a lot of cross border activities such as movement of all forms of vehicles and other human activities take place along the major roads in the area thereby leading to heavy metals pollution of the roadside soils. Hence, there is a need for this study to determine heavy metals ( $\mathrm{As}, \mathrm{Cr}, \mathrm{Mn}, \mathrm{Fe}, \mathrm{Ni}, \mathrm{Pb}, \mathrm{Zn}, \mathrm{Cd}$, and $\mathrm{Cu}$ ) in roadside soils from some major roads in Maiduguri, Borno State, Nigeria.

\section{Materials and Methods}

\subsection{Sampling Area}

Sample collections were carried out according to the methods described by Radojevc and Bashin, (1999) [14]. Roadside soil samples were collected from Maiduguri, Metropolis, Borno State. Maiduguri is located at longitude $11^{\circ} 13^{\prime} \mathrm{N}$ and latitude $13^{\circ} 05^{\prime} \mathrm{E}$. The city is about $355 \mathrm{~m}$ above sea level, located within the Sudan Savannah zone (Map 1) (GIS, 2016). The following seasons have been identified; cool, (hamattan) season (October-March) hot, dry season (April-June) and rainy season (July-September). Temperature is high all the year round, with hot season temperature ranging from $39^{\circ} \mathrm{C}-40^{\circ} \mathrm{C}$ under the shade [15].

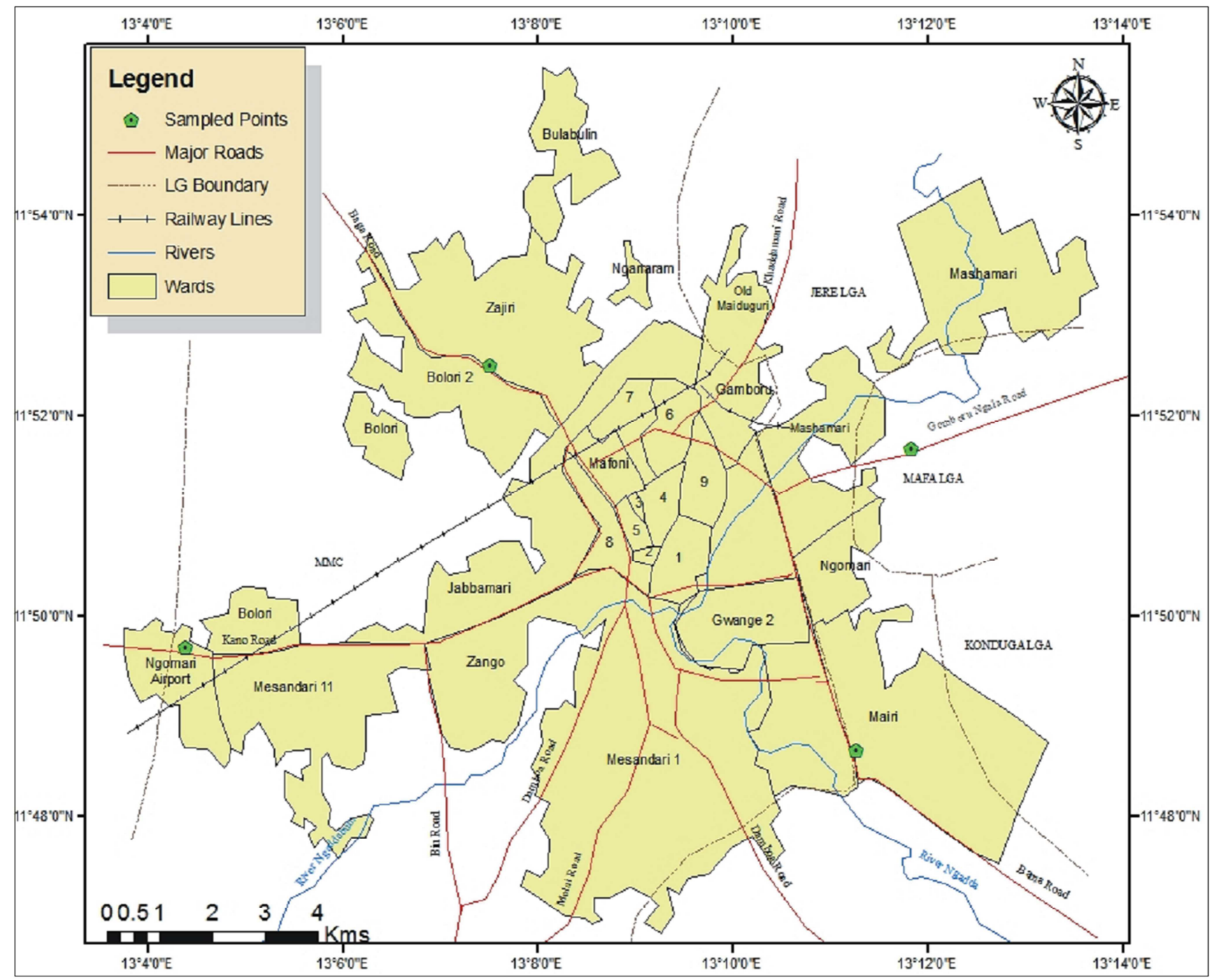

Figure 1. Map of Maiduguri Sampling points [Source: GIS, 2016].

\subsection{Sample Collection Points}

Samples were collected along some major roads (Bama road, Baga road, Ngala road and Jos road) (Map 2) (GIS, 2016). At each of the sample point, samples were collected at the edge of the road $0-2 m$ and $2-5 \mathrm{~cm}$ away from the edge of the road. At each of the distance, soil samples were collected at a depth of $0-2 m$ and 2-5 $\mathrm{cm}$ by using auger of 2-5 $\mathrm{cm}$ diameter for each road, the samples were homogenized to obtain two representative samples. Roadside soil samples were placed in clean plastic bags that are properly labeled and transported to the Department of Chemistry laboratory, University of Maiduguri pending preparation and analysis.

The traffic volume was determined as previously described 
by Radojevc and Bashin, (1999) with slight modification [14]. The traffic density around the four sample locations was carried out using visual counting on the number of vehicles passing one both side of the road in each of the sample locations. Two field assistants were place mounting at each particular sample location by $6 \mathrm{am}$, with one person counting on one side of the road. The procedure continued until $6 \mathrm{pm}$ where the exercise closed for the day. This went on for four weeks, while the field assistants were supervised to ensure successfully counting in all the sample locations. This was done in order to study the relationship between the number of vehicles passing these routes and their influence on heavy metal concentration of the roadside soils.

\subsection{Methods of Heavy Metal Pollution Assessment}

\subsubsection{Sample Preparation}

Sample collections were carried out according to the methods described by Radojevc and Bashin, (1999) [14]. All roadside soil samples were dried and ground, using a pestle and mortar to ensure homogeneity. These were sieved through a $2 \mathrm{~mm}$ mesh sieve. The samples were place in clean plastic bags and sealed pending digestion and analysis.

\subsubsection{Digestion of Soil Samples for Heavy Metal Determination}

Sample collections were carried out according to the methods described by APA, (1992) and adopted by Radojevc and Bashin, (1999) [14, 16]. Two grams (2 $g$ ) of the oven dried roadside soil samples were weighed into a well washed glass beaker. Soil samples were digested by the addition of $20 \mathrm{~cm}^{3}$ of aqua regia mixture of $\mathrm{HCl}$ and $\mathrm{HNO}_{3}$ (ratio 3:1) and $10 \mathrm{~cm}^{3}$ of $30 \% \mathrm{H}_{2} \mathrm{O}_{2}$ was added in small portions to avoid any possible over flow leading to loss of material from the beaker. The beaker wall and watch glass were washed with distilled water and the samples were filtered out to separate the insoluble solid from the supernatant liquid. The volume was adjusted to $100 \mathrm{~cm}^{3}$ with distilled water.

\subsubsection{Elemental Analysis of Samples}

Determination of $\mathrm{As}, \mathrm{Cd}, \mathrm{Cu}, \mathrm{Co}, \mathrm{Cr}, \mathrm{Fe}, \mathrm{Ni}, \mathrm{Pb}$ and $\mathrm{Zn}$ were made directly on each final solution using Perkin-Elmer analyst 300 atomic absorption spectroscopy (AAS).

Standard solutions of each element $\mathrm{As}, \mathrm{Cd}, \mathrm{Cu}, \mathrm{Co}, \mathrm{Cr}, \mathrm{Fe}$, $\mathrm{Ni}, \mathrm{Pb}$ and $\mathrm{Zn}$ were prepared according to $S c 200$ manufacturer for atomic absorption spectroscopy. A Known $1000 \mathrm{mg} / \mathrm{l}$ concentrations of the metal solution were prepared from their salts.

Data collected were subjected to one-way analysis of variance (ANOVA), this was used to assess whether heavy metals varied significantly between location and distances from the road. Probability less than $0.05(\mathrm{p}<0.05)$ were considered statistically significant.

\section{Results and Discussion}

\subsection{Concentration of Some Heavy Metals in Road Side Soil}

The concentrations of some heavy metals ( $\mathrm{As}, \mathrm{Cr}, \mathrm{Mn}, \mathrm{Fe}$,
$N i, P b, Z n, C d$, and $C u$ ) with respect to depth and distances from the road within Baga Road in Maiduguri Metropolis are presented in Table 1 The mean concentrations ranges from $0.80 \pm 0.01$ to $2.9 \pm 0.02 \mathrm{mg} / \mathrm{kg} ; 17.00 \pm 0.01$ to $20.40 \pm 0.03$ $\mathrm{mg} / \mathrm{kg} ; 40.80 \pm 0.02$ to $173.40 \pm 0.04 \mathrm{mg} / \mathrm{kg} ; 1185.00 \pm 0.04$ to $3818.70 \pm 0.0011 \mathrm{mg} / \mathrm{kg} ; 0.70 \pm 0.02$ to $27.00 \pm 0.02 \mathrm{mg} / \mathrm{kg}$; $5.90 \pm 0.04$ to $30.8 \pm 0.04 \mathrm{mg} / \mathrm{kg} ; 37.95 \pm 0.03$ to $192.21 \pm 0.07$ $\mathrm{mg} / \mathrm{kg} ; 0.10 \pm 0.10 \mathrm{mg} / \mathrm{kg}$ and $3.90 \pm 0.4$ to $12.80 \pm 0.03 \mathrm{mg} / \mathrm{kg}$ respectively. The highest concentrations of $3818.70 \pm 0.0011$ $\mathrm{mg} / \mathrm{kg}$ for $\mathrm{Fewere}$ observed at a distance of $2-5 \mathrm{~cm}$ while the least value of $0.10 \pm 0.10 \mathrm{mg} / \mathrm{kg}$ for $C d$ was observed at a distance of $0-2 m$.

The concentrations of some heavy metals ( $\mathrm{As}, \mathrm{Cr}, \mathrm{Mn}, \mathrm{Fe}$, $\mathrm{Ni}, \mathrm{Pb}, \mathrm{Zn}, \mathrm{Cd}$, and $\mathrm{Cu}$ ) with respect to depth and distances from the road within Bama Road in Maiduguri Metropolis are presented in Table 2. The mean concentrations ranges from $0.40 \pm 0.01$ to $4.40 \pm 0.01 \mathrm{mg} / \mathrm{kg} ; 14.10 \pm 0.07$ to $21.50 \pm 0.02 \mathrm{mg} / \mathrm{kg} ; \quad 9.60 \pm 0.01$ to $58.90 \pm 0.07 \mathrm{mg} / \mathrm{kg}$; $1253.50 \pm 0.04$ to $2874.50 \pm 0.04 \mathrm{mg} / \mathrm{kg} ; 1.90 \pm 0.03$ to $7.5 \pm 0.07$ $\mathrm{mg} / \mathrm{kg} ; \quad 11.30 \pm 0.09$ to $928.5 \pm 0.04 \mathrm{mg} / \mathrm{kg} ; 9.86 \pm 0.05$ to $329.11 \pm 0.07 \mathrm{mg} / \mathrm{kg} ; \quad 0.20 \pm 0.02 \mathrm{mg} / \mathrm{kg}$ and $2.10 \pm 0.00$ to $373.00 \pm 0.04 \mathrm{mg} / \mathrm{kg}$ respectively. The highest concentrations of $2874.5 \pm 0.04 \mathrm{mg} / \mathrm{kg}$ for $\mathrm{Fe}$ were observed at a distance of $2-5 \mathrm{~cm}$. while the least value of $0.20 \pm 0.02 \mathrm{mg} / \mathrm{kgfor} C d$ was observed at a distance of $0-2 \mathrm{~m}$.

The concentrations of some heavy metals ( $\mathrm{As}, \mathrm{Cr}, \mathrm{Mn}, \mathrm{Fe}$, $\mathrm{Ni}, \mathrm{Pb}, \mathrm{Zn}, \mathrm{Cd}$, and $\mathrm{Cu}$ ) with respect to depth and distances from the road within Kano/Jos Road in Maiduguri Metropolis are presented in Table 3. The mean concentrations ranged from $1.80 \pm 0.03$ to $13.80 \pm 0.12 \mathrm{mg} / \mathrm{kg} ; 11.40 \pm 0.08$ to $16.00 \pm 0.05 \mathrm{mg} / \mathrm{kg} ; \quad 10.82 \pm 0.03$ to $28.3 \pm 0.05 \mathrm{mg} / \mathrm{kg}$; $1182.40 \pm 0.04$ to $2454.70 \pm 0.02 \mathrm{mg} / \mathrm{kg} ; \quad 0.02 \pm 0.01$ to $78.00 \pm 0.07 \mathrm{mg} / \mathrm{kg} ; 0.10 \pm 0.02$ to $0.07 \pm 0.01 \mathrm{mg} / \mathrm{kg} ; 0.08 \pm 0.12$ to $0.23 \pm 0.06 \mathrm{mg} / \mathrm{kg} ; 0.20 \pm 0.02 \mathrm{mg} / \mathrm{kg}$ and $2.30 \pm 0.01$ to $4.70 \pm 0.03 \mathrm{mg} / \mathrm{kg}$; respectively. The highest concentrations of $2454.70 \pm 0.02 \mathrm{mg} / \mathrm{kg}$ for $\mathrm{Fe}$ were observed at a distance of 2$5 \mathrm{~cm}$ while the least value of $0.02 \pm 0.01 \mathrm{mg} / \mathrm{kg}$ was observed at a distance of 0-2 $\mathrm{m}$.

The concentrations of some heavy metals ( $\mathrm{As}, \mathrm{Cr}, \mathrm{Mn}, \mathrm{Fe}$, $\mathrm{Ni}, \mathrm{Pb}, \mathrm{Zn}, \mathrm{Cd}$, and $\mathrm{Cu}$ ) with respect to depth and distances from the road within Ngala Road in Maiduguri Metropolis are presented in Table 4 . The mean concentrations ranged from $0.05 \pm 0.02$ to $1.10 \pm 0.01 \mathrm{mg} / \mathrm{kg} ; 15.6 \pm 0.05$ to $23.5 \pm 0.07$ $\mathrm{mg} / \mathrm{kg} ; 32.50 \pm 0.03$ to $114.0 \pm 0.01 \mathrm{mg} / \mathrm{kg} ; 1195.60 \pm 0.08$ to $13491.70 \pm 0.07 \mathrm{mg} / \mathrm{kg} ; 0.09 \pm 0.02$ to $11.60 \pm 0.07 \mathrm{mg} / \mathrm{kg}$; $0.90 \pm 0.03$ to $13.10 \pm 0.05 \mathrm{mg} / \mathrm{kg} ; 5.60 \pm 0.01$ to $170.10 \pm 0.01$ $\mathrm{mg} / \mathrm{kg} ; \quad 0.10 \pm 0.02$ to $0.87 \pm 0.04 \mathrm{mg} / \mathrm{kg}$ and $0.84 \pm 0.03$ to $9.10 \pm 0.02 \mathrm{mg} / \mathrm{kg}$ respectively. The highest concentrations of $13491.7 \pm 0.07 \mathrm{mg} / \mathrm{kg}$ for $\mathrm{Fe}$ were observed at a distance of 2$5 \mathrm{~cm}$ while the least value of $0.02 \pm 0.02 \mathrm{mg} / \mathrm{kg}$ for $\mathrm{Ni}$ was observed at a distance of $0-2 m$.

\subsection{Concentration of Some Heavy Metals in Relation to Traffic Volume Count}

The mean concentrations of heavy metals (As, $\mathrm{Cr}, \mathrm{Mn}, \mathrm{Fe}$, $\mathrm{Ni}, \mathrm{Pb}, \mathrm{Zn}, \mathrm{Cd}$, and $\mathrm{Cu}$ ) in relation to traffic volume in Maiduguri metropolis are presented in Table 5. The mean 
concentrations ranged from 2.7 to $21 \mathrm{mg} / \mathrm{kg} ; 54.7$ to 76.4 $\mathrm{mg} / \mathrm{kg} ; 96.8$ to $332.8 \mathrm{mg} / \mathrm{kg} ; 6103.9$ to $17256.39 \mathrm{mg} / \mathrm{kg} ; 9.4$ to $79.7 \mathrm{mg} / \mathrm{kg} ; 38.2$ to $1742.8 \mathrm{mg} / \mathrm{kg} ; 61.47$ to $402.39 \mathrm{mg} / \mathrm{kg}$; 0.1 to $0.5 \mathrm{mg} / \mathrm{kg}$ and 14.2 to $423.0 \mathrm{mg} / \mathrm{kg}$ respectively. The highest concentrations of $17256.6 \mathrm{mg} / \mathrm{kg}$ for $\mathrm{Mn}$ were observed at Bama road while the least value of $0.1 \mathrm{mg} / \mathrm{kg}$ was observed at Kano/Jos road for $Z n$. The highest level of traffic volume count was determined at Bama road with 5295 while the least traffic volume count was observed at Ngala road with 3344 .

Table 1. Mean Concentrations of Some Heavy Metals in Road Side Soil Samples from Baga Road.

\begin{tabular}{|c|c|c|c|c|c|c|c|c|c|}
\hline \multicolumn{10}{|c|}{ Concentration in $\mathrm{mg} / \mathrm{kg}$} \\
\hline Depth & As & $\mathrm{Cr}$ & $M n$ & $\mathrm{Fe}$ & $\mathrm{Ni}$ & $P b$ & $Z n$ & $C d$ & $\mathrm{Cu}$ \\
\hline$S_{2}$ & & & & & & & & & \\
\hline $0-2 m$ & $2.20 \pm 0.01$ & $19.10 \pm 0.09$ & $40.80 \pm 0.02$ & $1185.00 \pm 0.04$ & $0.70 \pm 0.02$ & $5.90 \pm 0.04$ & $37.95 \pm 0.03$ & N.D & $6.50 \pm 0.08$ \\
\hline $\begin{array}{l}2-5 \mathrm{~cm} \\
S_{1}\end{array}$ & $2.90 \pm 0.02$ & $17.00 \pm 0.01$ & $52.8 \pm 0.06$ & $2523.40 \pm 0.07$ & N.D & $26.40 \pm 0.02$ & $192.21 \pm 0.07$ & N.D & $12.80 \pm 0.03$ \\
\hline $0-2 m$ & $0.80 \pm 0.01$ & $20.40 \pm 0.03$ & $173.4 \pm 0.04$ & $1882.20 \pm 0.08$ & $78.00 \pm 0.07$ & $18.8 \pm 0.01$ & $39.00 \pm 0.06$ & $0.10 \pm 0.10$ & $3.90 \pm 0.04$ \\
\hline $2-5 \mathrm{~cm}$ & $2.50 \pm 0.01$ & $19.00 \pm 0.05$ & $65.9 \pm 0.14$ & $3818.70 \pm 0.11$ & $1.00 \pm 0.04$ & $30.8 \pm 0.04$ & $109.37 \pm 0.03$ & N.D & $6.30 \pm 0.03$ \\
\hline
\end{tabular}

Key:

$\mathrm{S}_{1}=$ Edge of the Road

$\mathrm{S}_{2}=5$ meters Away from Road

Table 2. Mean Concentrations of Some Heavy Metals in Road Side Soil Samples from Bama Road.

\begin{tabular}{|c|c|c|c|c|c|c|c|c|c|}
\hline \multicolumn{10}{|c|}{ Concentration in $\mathrm{mg} / \mathrm{kg}$} \\
\hline Depth & As & $\mathrm{Cr}$ & $M n$ & $F e$ & $\mathrm{Ni}$ & $P b$ & $Z n$ & $C d$ & $\boldsymbol{C u}$ \\
\hline$S_{2}$ & & & & & & & & & \\
\hline $0-2 m$ & $0.70 \pm 0.01$ & $14.10 \pm 0.07$ & $9.60 \pm 0.01$ & $1253.50 \pm 0.04$ & N.D & $928.50 \pm 0.04$ & $23.15 \pm 0.04$ & N.D & $373.00 \pm 0.04$ \\
\hline $\begin{array}{l}2-5 \mathrm{~cm} \\
S_{1}\end{array}$ & $4.40 \pm 0.01$ & $21.50 \pm 0.02$ & $58.90 \pm 0.07$ & $2501.10 \pm 0.05$ & N.D & $785.80 \pm 0.01$ & $329.11 \pm 0.07$ & N.D & $10.60 \pm 0.03$ \\
\hline $0-2 m$ & $0.40 \pm 0.01$ & $18.50 \pm 0.07$ & $16.20 \pm 0.04$ & $2874.50 \pm 0.04$ & $1.90 \pm 0.03$ & $17.20 \pm 0.03$ & $9.86 \pm 0.05$ & N.D & $2.10 \pm 0.01$ \\
\hline $2-5 \mathrm{~cm}$ & $2.60 \pm 0.02$ & $15.4 \pm 0.04$ & $21.50 \pm 0.02$ & $1628.70 \pm 0.06$ & $7.5 \pm 0.07$ & $11.30 \pm 0.09$ & $40.27 \pm 0.22$ & $0.20 \pm 0.02$ & $37.30 \pm 0.01$ \\
\hline
\end{tabular}

Key:

$\mathrm{S}_{1}=$ Edge of the Road

$\mathrm{S}_{2}=5$ meters Away from Road

Table 3. Mean Concentrations of Some Heavy Metals in Road Side Soil Samples from Kano/Jos Road.

\begin{tabular}{|c|c|c|c|c|c|c|c|c|c|}
\hline \multicolumn{10}{|c|}{ Concentration in $\mathrm{mg} / \mathrm{kg}$} \\
\hline Depth & As & $\mathrm{Cr}$ & $M n$ & $F e$ & $\mathrm{Ni}$ & $P b$ & $Z n$ & $C d$ & $C u$ \\
\hline $\begin{array}{l}S_{2} \\
0-2 m\end{array}$ & $2.10 \pm 0.02$ & $14.70 \pm 0.04$ & $19.24 \pm 0.05$ & $1267.70 \pm 0.04$ & N.D & $0.11 \pm 0.01$ & $0.19 \pm 0.04$ & N.D & $3.80 \pm 0.04$ \\
\hline $\begin{array}{l}2-5 \mathrm{~cm} \\
S_{1}\end{array}$ & $3.30 \pm 0.03$ & $16.00 \pm 0.05$ & $23.18 \pm 0.03$ & $2454.70 \pm 0.02$ & N.D & $0.07 \pm 0.01$ & $0.23 \pm 0.06$ & $0.20 \pm 0.07$ & $4.70 \pm 0.03$ \\
\hline $0-2 m$ & $1.8 \pm 0.03$ & $12.60 \pm 0.11$ & $28.3 \pm 0.05$ & $1199.10 \pm 0.04$ & $78.00 \pm 0.07$ & $0.11 \pm 0.07$ & $0.08 \pm 0.12$ & N.D & $2.30 \pm 0.01$ \\
\hline $2-5 \mathrm{~cm}$ & $13.80 \pm 0.12$ & $11.40 \pm 0.08$ & $10.82 \pm 0.03$ & $1182.40 \pm 0.04$ & $0.02 \pm 0.01$ & $0.10 \pm 0.02$ & $0.1082 \pm 0.06$ & $0.20 \pm 0.02$ & $3.40 \pm 0.01$ \\
\hline
\end{tabular}

Key:

$\mathrm{S}_{1}=$ Edge of the Road

$\mathrm{S}_{2}=5$ meters Away from Road

Table 4. Mean Concentrations of Some Heavy Metals in Road Side Soil Samples from Ngala Road.

\begin{tabular}{|c|c|c|c|c|c|c|c|c|c|}
\hline \multicolumn{10}{|c|}{ Concentration in $\mathrm{mg} / \mathrm{kg}$} \\
\hline Depth & As & $\mathrm{Cr}$ & Mn & $\mathrm{Fe}$ & $\mathrm{Ni}$ & $P b$ & $Z n$ & $C d$ & $C u$ \\
\hline $\begin{array}{l}S_{2} \\
0-2 m\end{array}$ & $1.10 \pm 0.01$ & $20.80 \pm 0.08$ & $80.00 \pm 0.05$ & $1195.60 \pm 0.08$ & $11.60 \pm 0.07$ & $0.90 \pm 0.03$ & $5.60 \pm 0.01$ & $0.10 \pm 0.02$ & $1.02 \pm 0.02$ \\
\hline $\begin{array}{l}2-5 \mathrm{~cm} \\
S_{1}\end{array}$ & $0.80 \pm 0.01$ & $15.6 \pm 0.05$ & $43.50 \pm 0.03$ & $1243.30 \pm 0.05$ & $4.40 \pm 0.02$ & $13.10 \pm 0.05$ & $30.75 \pm 0.05$ & N.D & $3.30 \pm 0.04$ \\
\hline $0-2 m$ & $0.30 \pm 0.02$ & $16.50 \pm 0.03$ & $32.50 \pm 0.03$ & $1326.20 \pm 0.07$ & $3.00 \pm 0.04$ & $0.130 \pm 0.05$ & $19.01 \pm 0.02$ & $0.20 \pm 0.03$ & $9.10 \pm 0.02$ \\
\hline $2-5 \mathrm{~cm}$ & $0.05 \pm 0.02$ & $23.5 \pm 0.07$ & $114.0 \pm 0.01$ & $13491.70 \pm 0.07$ & $0.02 \pm 0.01$ & $0.09 \pm 0.02$ & $170.10 \pm 0.01$ & $0.87 \pm 0.04$ & $0.84 \pm 0.03$ \\
\hline
\end{tabular}

Key:

$\mathrm{S}_{1}=$ Edge of the Road

$\mathrm{S}_{2}=5$ meters Away from Road

\subsection{Heavy Metals in Roadside Soil Samples}

Lead $(\mathrm{Pb})$ : The highest $\mathrm{Pb}$ concentration in the road side soil was $928.50 \pm 0.04 \mathrm{mg} / \mathrm{kg}$ and was detected at Bama road, while lowest value of $0.07 \pm 0.01 \mathrm{mg} / \mathrm{kg}$ was detected at Kano/Jos road. The high concentration of $\mathrm{Pb}$ at Bama road, when compared to other locations might be due to the differences in traffic density, metals construction work, iron 
bending and welding of metals which is a common practice along the street of Maiduguri. The results also show that the levels of $P b$ in soil samples from all the sample locations were higher at the edge of the road than 5 meters away from the edge of the road. High values of $P b$ at the edge of the road when compared to 5 meters from the road could be attributed to more activities at the edges of the road due to traffic density. Wear and corrosion of vehicle parts might also be one of the potential sources of heavy metals. Results of analysis of variance confirmed a significant difference in $\mathrm{Pb}$ content in the all the sampling locations. The highest concentrations of $\mathrm{Pb}$ in the soil samples from the study area were higher than that reported by Charlsworth, et. al., (2003) of $48 \mathrm{mg} / \mathrm{kg}$, and was also higher than the range of 1.01-2.9 $m g / k g$ reported by Rashman and Shawabkeh, $(2006)[17,18]$. This value indicates a risk to environment in terms of pollutants.

Copper $(\mathrm{Cu})$ : Copper may be toxic to both humans and animals when its concentration exceeds safe limits [19]. The highest $\mathrm{Cu}$ concentration of $373.00 \pm 0.04 \mathrm{mg} / \mathrm{kg}$ in roadside soil was found at the Bama location, while Ngala road shows the lowest concentration of $0.84 \pm 0.03 \mathrm{mg} / \mathrm{kg}$. The high concentration of $\mathrm{Cu}$ at the Bama road when compared to other locations might be due to the differences in traffic density and metals construction work. High values of $C u$ at the edge of the road from all the locations when compared to 5 meters from the edge of the road might be due to corrosion of metallic car parts $[11,13]$.

Iron $(\mathrm{Fe})$ : Iron was found to be the dominant metals detected compared with others metals in the roadside soil. Iron is vital for almost all living organisms, participating in a wide variety of metabolic processes, including oxygen transport, DNA synthesis, and electron transport. It is known that adequate $\mathrm{Fe}$ in a diet is very important for decreasing the incidence of anemia [21]. High concentration of $\mathrm{Fe}$ (13491. $70 \pm 0.07 \mathrm{mg} / \mathrm{kg}$ ) in soil samples was observed at Ngala road, while Kano/Jos road shows the least concentration of $1182.40 \pm 0.04 \mathrm{mg} / \mathrm{kg}$. The high concentration of $\mathrm{Fe}$ detected at the Ngala road, when compared to other locations might be attributed to differences in traffic density [22]. Analysis of variance (ANOVA) confirmed a significant difference in the $\mathrm{Fe}$ content within the four sampling locations.

Nickel $(\mathrm{Ni})$ : Nickel pollution on a local scale is caused by emissions from vehicle engines that uses gasoline which contains $\mathrm{Ni}$ and by the abrasion and corrosion of $\mathrm{Ni}$ from vehicle parts [23]. The burning of fossil fuels as well as the refining of metals such as $\mathrm{Cu}$ introduces considerable amounts of $\mathrm{Ni}$ into the atmosphere [24]. The highest $\mathrm{Ni}$ concentration of $78.00 \pm 0.07 \mathrm{mg} / \mathrm{kg}$ in the soil samples was found at Baga and Kano/Jos road and it was not detected in some major roads. Very small values $(0.02 \pm 0.01 \mathrm{mg} / \mathrm{kg})$ of $\mathrm{Ni}$ was detected in Ngala and Kano/Jos road.. Analysis of variance (ANOVA) confirmed a significant difference in the $\mathrm{Ni}$ content in the four sampling locations, which shows that vehicular activities varied from one point to the other. Nickel values in the roadside soil samples from the four sample locations were found to be higher at the edge of the road than 5 meters away from the edges of the road.

Manganese $(M n)$ : The deficiency of manganese in the human body can produce severe skeletal and reproductive abnormalities in mammals. High doses of $M n$ produce adverse effects primarily on the lungs and brain. The highest $\mathrm{Mn}$ concentration of $173.40 \pm 0.04 \mathrm{mg} / \mathrm{kg}$ in the roadside soil samples was observed at Baga road, while the least value of $9.60 \pm 0.01 \mathrm{mg} / \mathrm{kg}$ was detected at Bama road. Analysis of variance (ANOVA) confirmed a significant difference in the $M n$ content within the four sampling locations, which shows that vehicular activities varied from one point to the other.

Cadmium (Cd): It was reported that cadmium is accumulated mainly in kidneys, spleen, and liver, and its blood serum level increases considerably following mushroom consumption [25]. Cadmium is now most commonly encountered in cadmium-nickel battery production, although it continues to be used in paints as well as in plastic production where it is an effective stabilizing agent. The highest $C d$ concentration of $0.87 \pm 0.04 \mathrm{mg} / \mathrm{kg}$ in the study roadside soil samples was observed at Ngala road and was not detected in some major roads. Ngala road showed the least concentration of $0.10 \pm 0.02 \mathrm{mg} / \mathrm{kg}$. Cadmium values in the roadside soil samples from the four sample locations were found to be higher at the edge of the road than 5 meters away from the edge of the road. Analysis of variance (ANOVA) confirmed a significant difference in the $C d$ content within the four sampling locations. The concentrations of $C d$ in the roadside soil samples world-wide has been reported to be $0.4-5.0 \mathrm{mg} / \mathrm{kg}$ [26]. Cadmium levels in the studied soil samples did not exceed this ranged.

Zinc $(Z n)$ : The highest $Z n$ concentration of $329.11 \pm 0.07$ $\mathrm{mg} / \mathrm{kg}$ in the roadside soil samples was observed at Bama road, while Kano/Jos road shows the lowest value of $0.08 .23 \pm 0.02 \mathrm{mg} / \mathrm{kg}$. The traffic situation in the study areas is regarded as a source of zinc in the roadside soil. Wear and corrosion of vehicle parts (brakes, tyres, radiators, body, and engine parts) might also be one of the potential sources of $Z n$ in roadside soil. $Z n$ values in the soil samples from the four sample locations were found to be higher at the edge of the road 5 meters from the road.

\subsection{Heavy Metals in Roadside Soil in Relation to Traffic Density}

Table 5 showed the total concentrations of some heavy metal in road side soil from the four sampling locations with respect to traffic volume. The total traffic volume for Baga road is 3979, 5295 for Bama Road, 4714 for Kano/Jos road and 4121 for Ngala road. The result show that Bama road recorded 5295 number of vehicles followed by Kano/Jos road with a total of 4714 , Ngala road with total of 4121 , while Baga road recorded a total of 3979 vehicles as presented in Table 5. Based on the result obtained in Table 5, the traffic situation in study areas might not be regarded as the only source of heavy metals in the roadside soil. 
Table 5. Total Concentrations of Heavy Metals ( $\mathrm{mg} / \mathrm{kg}$ ) in Relation to Traffic Volume.

\begin{tabular}{|c|c|c|c|c|c|c|c|c|c|c|}
\hline \multirow{2}{*}{ Location } & \multirow{2}{*}{$\begin{array}{l}\text { Traffic } \\
\text { Volume }\end{array}$} & \multicolumn{9}{|c|}{ Concentration in $\mathrm{mg} / \mathrm{kg}$} \\
\hline & & As & $\mathrm{Cr}$ & Mn & $\mathbf{F e}$ & $\mathbf{N i}$ & $\mathbf{P b}$ & $\mathbf{Z n}$ & Cd & $\mathrm{Cu}$ \\
\hline Baga Road & 3979 & 2.7 & 76.4 & 17256.5 & 270 & 19.09 & 14.425 & 225.46 & 0.3 & 40.8 \\
\hline Bama Road & 5295 & 21 & 54.7 & 6103.9 & 61.48 & 78 & 0.382 & 0.6147 & 0.4 & 14.2 \\
\hline Kano/Jos Road & 4714 & 8.4 & 75.5 & 9409.3 & 28 & 81.9 & 378.53 & 0.1 & 29.5 & 1.1 \\
\hline Ngala Road & 3344 & 8.1 & 69.5 & 8257.8 & 106.2 & 9.4 & 1742.8 & 402.39 & 0.2 & 423 \\
\hline
\end{tabular}

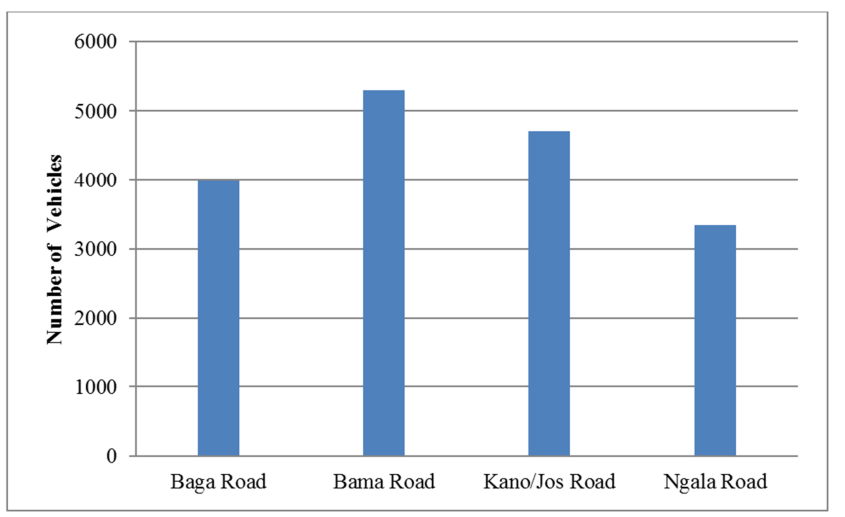

Figure 2. Total Number of Vehicles Passing the Four Sample Location for Four Weeks.

It can be observed from Figure 2, that Bama road with a high traffic volume shows relatively lower concentrations of heavy metals compared to areas of lower traffic volume. The concentration of these metals in the roadside soil samples may be attributed to other sources of metal pollution, since pollution is dynamic.

\section{Conclusion}

In all the sampling locations, $\mathrm{Mn}, \mathrm{Zn}, \mathrm{Fe}$ and $\mathrm{Pb}$ showed the highest concentrations of $137.4 \pm 0.04 \mathrm{mg} / \mathrm{kg}, 392.11 \pm 0.07$ $\mathrm{mg} / \mathrm{kg}, \quad 13491.70 \pm 0.07 \mathrm{mg} / \mathrm{kg}$ and $928.50 \pm 0.04 \mathrm{mg} / \mathrm{kg}$ respectively in roadside soil, while $C d$ showed the lowest concentration. The high concentration of these metals in the roadside soil samples may be attributed to metals construction work, Iron bending and welding of metals. At the same time, the traffic situation in this area of study might be regarded as a source of all the heavy metal content in roadside soil. Therefore, there is need to further study the concentrations of such heavy metals in agricultural soil, plants and vegetables grown in that area, animals that fed on the plants and any other source that directly or indirectly link to the source of food of the populace. It is also recommended that regular monitoring of levels of heavy metal in major roads of Maiduguri Metropolis is encouraged to ensure suitable management of the urban environment and reduction of traffic related contamination of road side soils.

\section{References}

[1] Lagerweriff, J. V. and Specht, A. W. (1970). Contamination of Roadside Soil and Vegetation with Cadmium, Nickel, Lead and Zinc. Environmental Science Technology, 4: 583-586.
[2] Ademoroti, C. M. A. (1992). "Blood lead levels in people living in traffic areas of Lagos" Teaching Monograph, Chemistry Department. University of Benin. pp 54-76.

[3] Hui, Z., Caiqiu, W., Jiping, G., Xuyin, Y., Qiao, W., Wenming, P., Tao, L., Jie, Q. and Hanpei, Z. (2017). Assessment of Heavy Metal Contamination in Roadside Soils Along the Shenyang-Dalian Highway in Liaoning Province, China. Pol. J. Environ. Stud., 26 (4): 1539-1549.

[4] Chen, X., Xia, X., Zhao, Y. and Zhang, P. (2010). Heavy metal concentrations in roadside soils and correlation with urban traffic in Beijing, China. Journal of Hazardous Materials, 181: 640-646.

[5] Adedeji, O. H., Olayinka, O. O. andOyebanji, F. F. (2013). Assessment of Traffic Related Heavy Metals Pollution of Roadside Soils in Emerging Urban Centres in Ijebu-North Area of Ogun State, Nigeria. J. Appl. Sci. Environ. Manage, 17 (4): 509-514.

[6] Wang, M. and Zhang, H.(2018). Accumulation of Heavy Metals in Roadside Soil in Urban Area and the Related Impacting Factors. Int. J. Environ. Res. Public Health, 15: 1064; doi: 10.3390/ijerph15061064.

[7] Aslam, J., Ahmad Khan, S. and Haque Khan, S. (2013). Heavy metals contamination in roadside soil near different traffic signals in Dubai, United Arab Emirates. Journal of Saudi Chemical Society, 17: 315-319.

[8] Mmolawa, K. B., Likuku, A. S. and Gaboutloeloe, G. K.(2011). Assessment of heavy metal pollution in soils along major roadside areas in Botswana. African Journal of Environmental Science and Technology, 5 (3): 186-196.

[9] Akbar, K. F., Hale, W. H. G., Headley, A. D. and Athar, M. (2006). Heavy Metal Contamination of Roadside Soils of Northern England. Soil and Water Res., 1 (4): 158-163.

[10] Harrison, R. M., Laxen, D. P. H. and Wilson, S. J. (1981). Chemical Association of Lead, Cadmium, Copper, and Zinc in Street Dusts and Roadside Soils. Environmental Science and Technology, 15: 1378-1383.

[11] Ho, Y. B. and Tai, K. M. (1988). Elevated Levels of Lead and Other. Metals in Roadside Soils and Grass and their use to monitor aerial Metal Depositions in Hong Kong. Environmental Pollution Journal, 49: 37-51.

[12] Otte, M. L., Bestebroar, S. J., Vander, J. M., Rozema, J. and Broekman, R. A. (1991). A Survey of Zinc, Copper and Cadmium Concentrations in Salt Marsh Plants along the Dutch Coast. Environmental Pollution, 72: 175-189.

[13] Mateu, J., Forteza, R., Cerda, V. and Colomaltes, M. (1995). Comparison of Various Methods for the Determination of Inorganic Species in Airborne Atmospheric Particulates. Continues Journal of Water, Air, Soil, and Pollution, 84: 61-79.

[14] Radojevc, M. and Bashin, N. V, (1999). Practical Environmental Analysis. Royal Society of Chemistry and Thomas Graham House, Cambridge, 180-430. 
[15] Alaku, S. O. and Moruppa S. M. (1998). Organ Weight Loss in Goats during Long Dry Season in the Sahel Region of West. African Journal Arid Zone Agriculture, 1: 23-24.

[16] Akpan, I. O. and William, E. S. (2014). Assessment of Elemental Concentrations of Roadside Soils in Relation to Traffic Density in Calabar, Nigeria. International Journal of Science and Technology Research, 3: 9.

[17] APHA. (American Public Health Association) (1992). Standard Methods for the Examination of Water and Wastewater (16th Ed.). New York, pp. 75-86.

[18] Charlesworth, S., Everett, M., McCarthy, R., Ordonez, A. and De-Miguel, E. (2003). A comparative study of heavy metal concentration and distribution in deposited street dusts in a large and a small urban area: Birmingham and Coventry, West Midlands, UK. Environment International, 29: 563-573.

[19] Al-Khashman, O. and Shawabkeh, R. (2006). Metal distribution in soils around the cement factory in southern Jordan. Environmental Pollution, 140: 387-394.

[20] Bakırdere, S., and Yaman, M. (2008). Determination of lead, cadmium and copper in roadside soil and plants in Elazig, Turkey. Environmental Monitoring and Assessment, 136 (13): 401-410.
[21] Al-Khashman, O. A. (2004). Heavy metal distribution in dust, street dust and soil from the work place in Karak Industrial Estate, Jordan. Atmospheric Environment, 38: 6803-6812.

[22] Lynch, S. R., and Baynes, R. D. (1996). Deliberations and evaluations of the approaches, end points and paradigms for iron dietary recommendations. The Journal of Nutrition, 126: 2404-2409.

[23] Adachi, K. and Tainosho, Y. (2004). Characterization of heavy metal particles embedded in tire dust. Environment International, 30: 1009-1017.

[24] Al-Shayep, S. M., and Seaward, M. R. D. (2001). Heavy metal content of roadside soils along ring road in Riyadh (Saudi Arabia). Asian Journal of Chemistry, 13: 407-423.

[25] Lee, P., Yu, Y., Yun, S. and Mayer, B. (2005). Metal contamination and solid phase partitioning of metals in urban roadside sediments. Chemosphere, 60 (5): 672-689.

[26] Kalac, P. and Svoboda, L. (2001). A review of trace element concentration in edible mushrooms. Food Chemistry, 69: 273281.

[27] Fergusson, J. E., and Kim, N. D. (1991). Trace elements in street and house dusts: sources and speciation. Science of the Total Environment, 100: 125-150. 